\title{
An assessment of the preoperative information given to patients in the province of Karaman ${ }^{1}$
}

\author{
Ali Şahin ${ }^{2}$ \\ Fatma Ayhan ${ }^{3}$ \\ Hacer Sönmezer Öcal ${ }^{4}$ \\ Aliye Çayır ${ }^{5}$
}

\begin{abstract}
The purpose of this research was to determine the status of information provision for patients in the preoperative period. Two hundred fifty patients undergoing surgery in the Karaman Public Hospital. A questionnaire prepared by the authors based on information in the literature and consisting of questions intended to determine patients' sociodemographic characteristics and the preoperative provision of information was used as a data collection tool. Data were expressed as number, percentage, mean and standard deviation. Mean age of patients was $45 \pm 21.08$ years. We determined that $47.2 \%$ had been given information concerning preoperative procedures and preoperative preparations, and that $7.6 \%$ had been given this information by nurses. In the light of the study findings, we conclude that physicians and nurses need to be more proactive in providing patients with preoperative information and that, considering the forgetfulness factor, such information should also be provided in written form.
\end{abstract}

Keywords: patient education; information requirement; preoperative nursing; preoperative period; surgical nursing

\section{Introduction}

The provision of information to patients and families in the preoperative period is of the greatest importance, since being scheduled to receive surgical treatment is a frightening, stressful and unfamiliar situation for most patients (Aksoy, 2012). Information provided preoperatively contributes to the patient knowing what will happen at each stage of a surgical procedure, and to improving physical and psychological well-being and also surgical outcomes (Erdil \& Elbaş, 2000; Kane, 2000; Yavuz, 2011; Dönmez \& Özbayır, 2008; Özbaş, 2011). Guidelines published by the

\footnotetext{
${ }^{1}$ The study was presenten asan poster papers in $7^{\text {th }}$ National Nursing Edication Congres, 8-10 April 2015

${ }^{2}$ Prof. Dr., Karamanoglu Mehmetbey University, Health College, Karaman, alisahin@,kmuedu.tr 3Lecturer, Karamanoglu Mehmetbey University, Health College, Karaman. f.kucuksumbul@gmail.com

${ }^{4}$ Lecturer, Karamanoglu Mehmetbey University, Health College, Karaman. hcrsnmzr@gmail.com

${ }^{5}$ Lecturer, Necmettin Erbakan University, Health Sciences Faculty, Konya, aliye.cyr@gmail.com
} 
Şahin, A., Ayhan, F., Öcal, HS., Çayır, A. (2015). An assessment of the preoperative information given to patients in the province of Karaman. International Journal of Human Sciences, 12(2), 1111-1119. doi: 10.14687/ijhs.v12i2.3348

Joint Commission on Accreditation of Healthcare Organizations (JCAHO) also contain information and principles related to information to be given to patients and families on the subjects of the operation concerned, the recovery process, sutures, dressings, drains, feeding tubes, pain control and diet.

The European Office of the WHO (World Heath Organization) stresses the importance of health education in 'everyone achieving health targets,' and emphasized that nurses are all health instructors. It also describes the provision of health education for patients and families as one of nurses' health education responsibilities. The nurse assumes primary responsibility for clarifying information given by physicians and the rest of the health team that is necessary for overcoming problems (Taşocak, 2007; Kaya, 2009). Being capable of assisting with providing information, using pamphlets, written recommendations and other materials on the subject and facilitating patient compliance and comprehension all increase the effectiveness of education as the nurse discharges this professional role (Aksoy, 2012). Failure to provide sufficient information in the preoperative period leads to emotional difficulties, such as concerns over the decision to operate and waiting period, anxiety, fear of pain and uncertainty over the future, depression, anger and inability to perform personal functions after surgery. The risk of postoperative complications increases as a result, and lengths of hospital stay are prolonged (Kane, 2000; Özbayır et al, 2003; Oğuzalp et al, 2010; Yavuz, 2011).

Patients who receive well-planned preoperative information have lower analgesic, antiemetic, sedative and hypnosis requirements, have shorter postoperative hospital stays and increased satisfaction, are better able to cope with the effects of surgery and heal faster, meaning that they are able to return work and daily life earlier (Sayın \& Aksoy 2000; Şendir, 2000; Y1lmaz, 2002; Oetker-Black et al, 2003; Walker, 2007; Çetinkaya \& Karabulut, 2010; Gräwe et al, 2010; Jlala et al, 2010; Yavuz, 2010; Aksoy, 2012). However, studies have reported that individuals undergoing surgery need more information than they receive (Dolgun \& Dönmez 2010; Şendir \& Babadağ, 2000; Türgay, 2011), that the information provided is complex and difficult to understand (Hopper et al., 1995, Hopper et al., 1998, McCormack et al., 1997, Lynöe et al., 1991) and that patients may be unable to remember it. Many authors therefore say that information should be given in combined verbal and written form (Guillod 1995, Meuli and Kuhn 1995, Payllier 1995, Haller et al., 1999, Kessler et al., 2000).

Despite the great importance of preoperative education, the number of studies assessing the provision of preoperative information by nurses, in both the Turkish-language and foreign literature, is very low. This research was therefore intended to assess the provision of preoperative information for patients in surgical departments. 
Şahin, A., Ayhan, F., Öcal, HS., Çayır, A. (2015). An assessment of the preoperative information given to patients in the province of Karaman. International Journal of Human Sciences, 12(2), 1111-1119. doi: 10.14687/ijhs.v12i2.3348

\section{Materials and methods}

\section{Type, place and date of research}

The study population of the descriptive and cross-sectional study consisted of patients undergoing surgery in Karaman Public Hospitals Union General Surgery, Urology, Orthopedic, Ear, Nose and Throat and Gynecology departments. The research sample consisted of patients meeting the inclusion criteria between 1 March and 30 May, 2013.

The inclusion criteria were;

- Age 18-65,

- No diagnosis of mental or psychological disease and not using drugs for such reasons,

- Surgery being elective,

- Willingness to participate in the study.

\section{Data collection form}

The study data were collected at face-to-face interviews using a two-part questionnaire prepared in the light of the literature (Bernier et al, 2003, Bulut, 2011, Özbaş, 2011; Yavuz 2011; Carpenito-Moyet, 2012; Aksoy et al., 2012). The first part of the questionnaire contained 8 questions inquiring into patients' health and sociodemographic characteristics, and the second consisted of 35 questions inquiring into receipt of preoperative information.

\section{Data analysis}

Data analysis was performed on Statistical Package for the Social Sciences (SPSS) software. Data were expressed as number, percentage, mean and standard deviation.

\section{Ethical issues}

Written approval for the study was granted by the Karaman Public Hospitals Union, and verbal consent was obtained from patients. All patients agreeing to take part and their families were informed about the aim of the study, the methodology and its expected benefits.

\section{Results}

Mean age of the patients in this study was 45 \pm 21.083 . Examination of patients' sociodemographic characteristics revealed that $70.8 \%$ were married, $50.8 \%$ were women, $54.8 \%$ were primary or middle school graduates, $41.2 \%$ were housewives. $93.2 \%$ had social security and $87.2 \%$ lived with their families (Table 1). In addition, $70.4 \%$ of patients had no chronic disease, $53.6 \%$ had previous experience of surgery, $47.2 \%$ of previously operated subjects had received preoperative information and $7.6 \%$ had received that information from nurses (Table 2). We also 
Şahin, A., Ayhan, F., Öcal, HS., Çayır, A. (2015). An assessment of the preoperative information given to patients in the province of Karaman. International Journal of Human Sciences, 12(2), 1111-1119. doi: 10.14687/ijhs.v12i2.3348

determined that $95.2 \%$ of patients had received preoperative education regarding their current operations, and that nurses + physicians had provided $60 \%$ of this (Table 2 ).

Examination of the information provided in the preoperative period and the mode of provision revealed that $94.4 \%$ of patients had received verbal information about the type of surgery to be performed, $92.8 \%$ about preoperative fasting, $89.2 \%$ about preoperative intestinal preparation, $88.4 \%$ about preoperative tests, $86.4 \%$ about preoperative treatments, and $84.8 \%$ about permission for surgery (Table 3). A further $88.4 \%$ of patients had received written information about preoperative tests and $39.6 \%$ about the operating theater.

\section{Discussion}

Patients who do not receive adequate preoperative information experience various emotional difficulties both before and after surgery. These include problems such as anxiety, fear of pain, fear of the unknown and the future, depression, anger and inability to perform personal functions after surgery. Preoperative education is therefore an important marker of the quality of surgical patient care. Nurses' being in possession of up-to-date information on the subject of patient education, the presence of sufficient infrastructure in institutions, awareness of the importance of the subject and planned patient education all increase the quality of care. The findings from this study are discussed below in order to determine the provision of preoperative information to patients in that context.

Both physicians and nurses provided information for $60 \%$ patients concerning preoperative procedures and preparations. Similarly, Dolgun and Dönmez (2010) reported that $42 \%$ of patients received information from both physicians and nurses, while Gürlek and Yavuz (2013) cited a figure of $61.9 \%$. Özbayır et al. (2003) reported that $59.15 \%$ of patients received information about surgery from physicians only, while Aygül and Ulupinar (2012) cited a figure of $72.3 \%$ and Kutlu and Çetinkaya (2004) reported that 'the majority' of patients received information from doctors alone. When nurses attach importance to and perform patient instruction, patients then assume responsibility for health care and are able to share anxieties and better comprehend the information provided. The levels of information provision in this research and other studies therefore apears to be insufficient.

Fifty percent of patients were given information about the items they needed to bring to hospital (Table 3). Dolgun and Dönmez (2010) reported that $66.7 \%$ of patients were informed what to bring with them to hospital, while Gürlek and Yavuz (2013) cited 77.7\%. These findings are in agreement with our own results. In terms provision of information concerning preoperative 
Şahin, A., Ayhan, F., Öcal, HS., Çayır, A. (2015). An assessment of the preoperative information given to patients in the province of Karaman. International Journal of Human Sciences, 12(2), 1111-1119. doi: 10.14687/ijhs.v12i2.3348

tests, $88.4 \%$ received such information (Table 3). Dolgun and Dönmez (2010) reported a figure of $59.4 \%$ of patients and Gürlek and Yavuz (2013) of 85.7\%.

Informed preoperative consent has to be obtained from patients by law in order to protect their rights, autonomy and privacy. The nurse's ethical responsibility within the context of informed consent, acting as the patient's protector, permits the patient to understand information and take autonomous decisions. We determined that $84.8 \%$ of patients received information about consent forms for surgery (Table 3).

In this study, $64.4 \%$ of patients received information about where they would be taken after surgery (Table 3). Gürlek and Yavuz (2013) reported that 58.7\% of patients were given such information, while Dolgun and Dönmez (2010) cited 55.1\%. In addition, 69.6\% of patients in this study were given information concerning postoperative nutrition and diet (Table 3). Similarly, Dolgun and Dönmez (2010) reported that $66.7 \%$ of patients received such information, with Gürlek and Yavuz (2013) citing 60\%.

Our study showed that $53.6 \%$ of patients received information about postoperative deep respiration coughing exercises (Table 3). Kutlu and Çetinkaya (2004) reported that 9.3\% of nurses taught patients deep respiration coughing exercises in the preoperative period, while Dolgun and Dönmez (2010) reported that $31.9 \%$ of patients received such information while Gürlek and Yavuz (2013) reported a figure of 22.2\%. Although our findings for respiration and coughing exercises were higher than those of other studies, considering the potential complications that may develop if these activities are not performed after surgery, we think that the level is still low.

\section{Conclusion}

Studies have revealed deficiencies in preoperative information provision. Physicians and nurses need to be more proactive in information provision, and since written information is more permanent that verbal information, we think that both verbal and written information need to be given. We recommend that pre-and postoperative information provision be adjusted to the patient's requirements, readiness, age and level of education and that effective information can be provided with the development of educational materials for patients (such as pamphlets and videos).

\section{Acknowledgments}

This research was supported by the scientific research projects of Karamanoglu Mehmetbey University (Project No. 34-M-12). 
Şahin, A., Ayhan, F., Öcal, HS., Çayır, A. (2015). An assessment of the preoperative information given to patients in the province of Karaman. International Journal of Human Sciences, 12(2), 1111-1119. doi: 10.14687/ijhs.v12i2.3348

\section{References}

Aksoy G, Kanan N, Akyolcu N. Cerrahi Hemşireliği. 1.Birinci baskı. İstanbul. Nobel Tip Kitabevleri, 2012;335-67.

Aygül S, Ulupınar S. Hemşirenin hasta eğitġmindeki rolüne yönelik hastaların görüşleri. Anadolu Hemşirelik Ve Sağlık Bilimleri Dergisi, 2012; 15(1):1-9.

Bernier MJ,Sanares DC, Owen SV, Newhouse PL. Preoperative Teaching Received and Valued in a Day Surgery Setting. Aorn Journal.2003: 77(3);563-82.

Bulut H. Ameliyat öncesi ve Ameliyat sonrası bakım. İçinde: Aşt TA, Karadağ A, editörler. Klinik uygulama becerileri ve yöntemleri. 1. bask1. Adana: Nobel tıp kitabevleri; 2011. p.128-65.

Carpenito-Moyet. 2010. Hemşirelik tanıları. (Erdemir F, Çev.). 13. Baskı, İstanbul, Nobel Tip Kitabevleri; 2012.s. 368-70.

Çetinkaya F, Karabulut N. Batın ameliyatı olacak yetişkin hastalara ameliyat öncesi verilen eğitimin kayg1 ve ağr1 düzeyine etkisi. Anadolu Hemşirelik ve Sağlık Bilimleri Derg, 2010; 13: 20-6.

Dolgun E, Dönmez YC. Hastaların ameliyat öncesi döneme ait bilgi gereksinimlerinin belirlenmesi. Maltepe Üniversitesi Hemşirelik Bilim ve Sanat Dergisi. 2010;3(3):10-16.

Dönmez YC, Özbayır T. Kaliteli Perioperatif Hemşirelik Bakım Skalası'nın türk hemşire ve hastaları için geçerlik ve güvenirliğinin incelenmesi. Ege Üniversitesi Hemşirelik Yüksekokulu Dergisi 2008;24(2):1-25.

Erdil F, Elbaş NÖ. Hasta yakınlarının ameliyat öncesi döneme ilişkin bilgi gereksinimleri, ameliyatı beklerken yaşadıkları duyguları ve ameliyathane bekleme salonuna ilişkin görüşleri. Hemşirelik Forumu Dergisi 2000;3(6):1-5.

Gräwe JS, Mirow L, Bouchard R, Lindig M. Impact of preoperative patient education on postoperative pain in consideration of the individual coping style. Schmerz 2010;24(6):57586.

Guillod O. Pour une meilleure information des patients: des brochures écrites. Schweiz Arzteztg. 1995;76:318-321.

Gürlek Ö, Yavuz M. Cerrahi kliniklerde çalışan hemşirelerin ameliyat öncesi hasta eğitimi uygulama durumları. Anadolu Hemşirelik Ve Sağlık Bilimleri Dergisi. 2013;16(1):8-15.

Haller U, Hepp H, Reinold E, Winter R. How much preoperative information? How can it be documented? [in German]. Gynakol Geburtshilfliche Rundsch. 1999;39:181-182.

Hopper KD, TenHave TR, Hartzel J. Informed consent forms for clinical and research imaging procedures: how much do patients understand? AJR Am J Roentgenol. 1995;164:493-496.

Hopper KD, TenHave TR, Tully DA, Hall TE. The readability of currently used surgical/procedure consent forms in the United States. Surgery. 1998;123:496-503.

Jlala HA, French JL, Foxall GL, Hardman JG, Bedfort NM. Effect of preoperative multimedia information on perioperative anxiety in patients undergoing procedures under regional anaesthesia. BrJ Anaesth 2010;104(3):369-74.

Joint Commission on Accreditation of Healthcare Organizations:Accreditation manual for hospitals, Chicago,2004, The Commission.

Kane L. Preoperative nursing management. In: Smeltzer SC, Bare B, eds. Brunner \& Suddarth's Textbook of Medical Surgical Nursing. 9th ed. Philadelphia: Lippincott; 2000. p.315-28. 
Şahin, A., Ayhan, F., Öcal, HS., Çayır, A. (2015). An assessment of the preoperative information given to patients in the province of Karaman. International Journal of Human Sciences, 12(2), 1111-1119. doi: 10.14687/ijhs.v12i2.3348

Kaya H. Sağlık hizmetlerinde hasta eğitimi ve hemşirenin sorumlulukları. Turkiye Klinikleri J Nurs Sci, 2009;1(1):19-23.

Kessler W, Faisst K, Kessler M, et al. Quality control in patient education: results of a patient survey about the patient education protocol of the Swiss Society of Surgery in 6 Swiss hospitals [in German]. Swiss Surg. 2000; 6:42-49.

Kutlu AK, Çetinkaya AÇ. Cerrahi servislerinde görev yapan hemşirelerin ameliyat öncesi ve sonrası bakıma ait uygulamaları: Manisa örneği. Hemşirelik Forumu Dergisi. 2004;7(2):68-77.

Lynöe N, Sandlund M, Dahlqvist G, Jacobsson L. Informed consent: study of quality of information given to participants in a clinical trial. BMJ. 1991;303:610-613.

McCormack D, Evoy D, Mulcahy D, Walsh M. An evaluation of patients comprehension of orthopaedic terminology: implications for informed consent. J R Coll Surg Edinb. 1997;42:33-35.

Meuli H, Kuhn H-P. Aufklärungspflicht: Weder Verängstigung noch Verdrängung. Schweiz Arzteztg. 1995;76:311.

Oetker-Black SL, Jones S, Esfok P, Ryan M, Gale N, Parker C. Preoperative teaching and hysterectomy outcomes. AORN, 2003;77(6):1215-1231.

Oğuzalp H, Pamuk AG, Öcal T. Günübirlik cerrahide ebeveyn anksiyetesinin ve beklentilerinin değerlendirilmesi. Türk Anesteziyoloji ve Reanimasyon Derneği Dergisi 2010;38(3):208-16.

Özbaş A. Ameliyat öncesi bakım uygulamaları. İçinde: Akyolcu N, Aksoy G, Kanan N, editorler. Cerrahi hemşireliği uygulama rehberi. 1. Baskı. Ankara: İstanbul tıp kitabevi yayıncılık; 2011. s.33-59.

Özbayır T, Demir F, Candan Y, Çoşkun İ, Dramalı A. Hastaların perioperatif döneme ilişkin

izlenimlerinin incelenmesi. Atatürk Üniversitesi Hemşirelik Yüksekokulu Dergisi 2003;6(1):14-23.

Payllier P. Rechtsprobleme der ärztlichen Aufklärung. Unter besonderer Berücksichtigung der spitalärztlichen Aufklärung. Zürich, Switzerland: Schulthess Polygraphischer Verlag Zürich; 1999. Zürcher Studien zum Privatrecht; Vol 145.

Sayin Y, Aksoy G. The effect of analgesia education on pain in patients undergoing breast spiers The surgical nurse as teacher and health promoter. İçinde. Manley K, Bellman (EDS.), Surgical Nursing: Advancing Practice. Churchill Livivgstone. London. 2000. p. 47-67.

Şendir M, Babadağ K. Total Kalça Protezi Ameliyatı öncesi hasta eğitiminin ameliyat sonrası fiziksel uyum ve yaşam kalitesine etkisi. hemşirelik bülteni 2000;12(46):27-42.

Taşocak G. Hasta eğitimi. İstanbul: İstanbul Üniversitesi Basım ve Yayınevi, 2007. p.61-93.

Türgay AS. Ameliyat öncesi, sırası ve sonrası bakım. İçinde: Ay FA, editör. Sağlık uygulamalarında temel kavramlar ve beceriler.1. Baskı. İstanbul: Nobel tp kitabevleri; 2011. s.642-71.

Walker JA. What Is The effect of preoperative information on patient satisfaction? $\mathrm{Br} \mathrm{J}$ Nurs, 2007;16(1):27-32.

Yavuz M, Cerrahi bakım. İçinde: Karadakovan A, Aslan EF, editörler. Dahili ve Cerrahi Hastalıklarda Bakım. 2. Bask1, Adana, Nobel Kitabevi; 2011.s.145-61.

Yılmaz M. Ameliyat Öncesi Öğretimin Ameliyat Sonrası Komplikasyonlara ve Hasta Memnuniyetine Etkisi. Hemşirelikte Araşturma Geliştirme Dergisi 2002;4(1):40-9. 
Şahin, A., Ayhan, F., Öcal, HS., Çayır, A. (2015). An assessment of the preoperative information given to patients in the province of Karaman. International Journal of Human Sciences, 12(2), 1111-1119. doi: 10.14687/ijhs.v12i2.3348

Table 1: Participants' sociodemographic characteristics

\begin{tabular}{|c|c|c|}
\hline Variables $(n=250 \quad)$ & No. & $\%$ \\
\hline \multicolumn{3}{|l|}{ Marital status } \\
\hline Single & 73 & 29.2 \\
\hline Married & 177 & 70.8 \\
\hline \multicolumn{3}{|l|}{ Sex } \\
\hline \multirow{2}{*}{$\begin{array}{l}\text { Male } \\
\text { Female }\end{array}$} & 123 & 49.2 \\
\hline & 127 & 50.8 \\
\hline \multicolumn{3}{|l|}{ Educational level } \\
\hline \multirow{4}{*}{$\begin{array}{l}\text { Literate } \\
\text { Primary/middle school } \\
\text { High school } \\
\text { University or above }\end{array}$} & 46 & 18.4 \\
\hline & 137 & 54.8 \\
\hline & 44 & 17.6 \\
\hline & 23 & 9.2 \\
\hline \multicolumn{3}{|l|}{ Social security } \\
\hline Yes & 233 & 93.2 \\
\hline No & 17 & 6.8 \\
\hline \multicolumn{3}{|l|}{ Income } \\
\hline \multirow{3}{*}{$\begin{array}{l}\text { Income less than outgoings } \\
\text { Income equal to outgoings } \\
\text { Income exceeding outgoings }\end{array}$} & 86 & 34.4 \\
\hline & 161 & 64.4 \\
\hline & 3 & 1.2 \\
\hline \multicolumn{3}{|l|}{ Household } \\
\hline \multirow{3}{*}{$\begin{array}{l}\text { Living alone } \\
\text { With family } \\
\text { With friends }\end{array}$} & 74 & 9.6 \\
\hline & 218 & 87.2 \\
\hline & 8 & 3.2 \\
\hline
\end{tabular}

Table 2: Information about health and disease

\begin{tabular}{lll}
\hline & \multicolumn{2}{c}{ Yes } \\
Variables (n=250) & No. & \% \\
\hline Chronic disease & 74 & 29.6 \\
\hline Previous experience of surgery & 134 & 53.6 \\
\hline Receipt of information about surgery in previous operations & 118 & 47.2 \\
\hline Who provided preoperative information in previous operations & & \\
Nurse & 19 & 7.6 \\
Physician & 29 & 11.6 \\
Nurse+Physician & 71 & 28.4 \\
\hline Provision of information about the current operation & 238 & 95.2 \\
\hline Who provided preoperative information in the current operation & & \\
Nurse & 40 & 20.8 \\
Physician & 52 & 20.8 \\
Nurse+Physician & 150 & 60.0 \\
\hline
\end{tabular}


Şahin, A., Ayhan, F., Öcal, HS., Çayır, A. (2015). An assessment of the preoperative information given to patients in the province of Karaman. International Journal of Human Sciences, 12(2), 1111-1119. doi: 10.14687/ijhs.v12i2.3348

\section{Table 3: Variables concerning information provided preoperatively}

\begin{tabular}{|c|c|c|c|c|}
\hline \multirow[t]{2}{*}{$(n=250)$} & \multicolumn{2}{|c|}{ Written } & \multicolumn{2}{|c|}{ Verbal } \\
\hline & No. & $\%$ & No. & $\%$ \\
\hline Do you know when you will have your operation? & 2 & 0.8 & 236 & 94.4 \\
\hline Were you informed what objects to bring to hospital? & 3 & 1.2 & 125 & 50.0 \\
\hline Were you told how to store your valuable possessions? & 1 & 0.4 & 114 & 45.6 \\
\hline Were you told about tests to be performed before your operation? & 221 & 88.4 & 221 & 88.4 \\
\hline Were you informed about the surgical consent form? & 15.0 & 6.0 & 212 & 84.8 \\
\hline Were you informed about treatments before surgery? & 3 & 1.2 & 216 & 86.4 \\
\hline $\begin{array}{l}\text { Was your preoperative routine drug or herbal medicine use evaluated, } \\
\text { and were you told whether to change the dose or stop taking them } \\
\text { altogether? }\end{array}$ & 2 & 0.8 & 149 & 59.6 \\
\hline $\begin{array}{l}\text { Were your cigarette and alcohol consumption evaluated and were you } \\
\text { informed about when to stop taking them? }\end{array}$ & 1 & 0.4 & 91 & 36.4 \\
\hline Were you informed about fasting before surgery? & 2 & 0.8 & 232 & 92.8 \\
\hline Were you informed about preoperative intestinal preparation? & 2 & 0.8 & 223 & 89.2 \\
\hline $\begin{array}{l}\text { Were you informed about preoperative venous, or if necessary urinary } \\
\text { catheter, and gastric tubes being inserted if necessary? }\end{array}$ & 2 & 0.8 & 143 & 69.2 \\
\hline Were you informed about the waiting room before surgery? & 1 & 0.4 & 113 & 45.2 \\
\hline Were you informed about the operating theater? & 99 & 39.6 & 99 & 39.6 \\
\hline $\begin{array}{l}\text { Were you informed about the members of the team responsible for your } \\
\text { care? }\end{array}$ & 1 & 0.4 & 122 & 48.8 \\
\hline Were you informed where you will be taken after surgery? & 0 & 0 & 160 & 64 \\
\hline Were you informed about nutrition and diet after surgery? & 1 & 0.4 & 174 & 69.6 \\
\hline Were you informed about the anesthetic to be used? & 4 & 1.6 & 172 & 68.8 \\
\hline Were you informed about tubes and drains to be placed postoperatively? & 2 & 0.8 & 91 & 36.4 \\
\hline Were you informed about postoperative pain? & 2 & 0.8 & 204 & 81.6 \\
\hline $\begin{array}{l}\text { Were you informed about postoperative soreness and dryness in the } \\
\text { throat? }\end{array}$ & 2 & 0.8 & 191 & 76.4 \\
\hline Were you informed about somnolence and forgetfulness after surgery? & 0 & 0 & 191 & 76.4 \\
\hline Were you informed about nausea and vomiting after surgery? & 0 & 0 & 192 & 76.8 \\
\hline $\begin{array}{l}\text { Were you informed about deep breathing coughing exercises after } \\
\text { surgery? }\end{array}$ & 0 & 0 & 134 & 53.6 \\
\hline Were you informed about leg and foot exercises after surgery? & 1 & 0.4 & 136 & 54.4 \\
\hline Were you informed about turning exercises after surgery? & 0 & 0 & 130 & 52 \\
\hline Were you informed about walking exercises after surgery? & 1 & 0.4 & 142 & 56.8 \\
\hline Were you informed about hospital rules? & 0 & 0 & 139 & 55.6 \\
\hline $\begin{array}{l}\text { Were you informed about undesirable conditions after surgery? } \\
\text { (Problems such as pain in the wound site, swelling, reddening, increased } \\
\text { temperature, leakage, increased body temperature or lethargy) }\end{array}$ & 0 & 0 & 168 & 67.2 \\
\hline $\begin{array}{l}\text { Were you informed about limitations after surgery (activities, nutrition, } \\
\text { drug use, sexual activity) }\end{array}$ & 0 & 0 & 188 & 75.2 \\
\hline Were you informed about surgical site care and dressings? & 0 & 0 & 172 & 68.8 \\
\hline Were you informed what times your family can visit you after surgery? & 0 & 0 & 165 & 66 \\
\hline Were you informed when you will be discharged? & 0 & 0 & 147 & 58.8 \\
\hline $\begin{array}{l}\text { Were you informed about bodily hygiene and when you can bathe after } \\
\text { surgery? }\end{array}$ & 0 & 0 & 124 & 49.6 \\
\hline $\begin{array}{l}\text { Have you been told whom you can go to for check-ups, and when and } \\
\text { how? }\end{array}$ & 0 & 0.4 & 147 & 58.8 \\
\hline $\begin{array}{l}\text { Have you been informed about the effect of your disease or operation } \\
\text { on your work life and when you can return to work? }\end{array}$ & 1 & 0.4 & 125 & 50 \\
\hline
\end{tabular}

